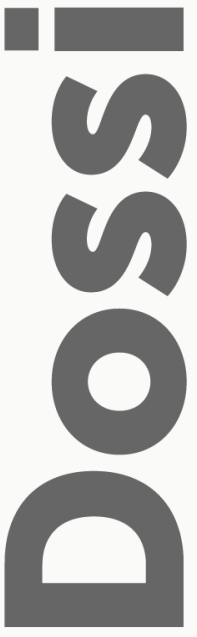

\title{
Uma epidemia chamada patriarcalismo e suas sequelas:
}

\author{
O caso "A menina morta" \\ An epidemic called patriarchalism and its aftermath: The \\ "A menina morta" case
}

\section{RESUMO}

O papel da segunda epidemia de febre amarela no Rio de Janeiro no romance A menina morta (1954), de Cornélio Penna (1896-1958), é singular. O episódio, além de sanitário, aglutinou-se à história, à vida social, à política, à economia, à produção cultural e literária. Tal caráter transversal contribui para transformá-lo em um instrumento crítico que ajuda a compreender o livro em questão, sobretudo no que tange ao patriarcalismo. Na medida em que aumenta a possibilidade de o Comendador, proprietário da fazenda na qual se desenvolve a narrativa, ter contraído febre amarela, vemos o sistema representado por ele mais e mais enfraquecido, debilitado. A partir desse quadro, pensamos nesse sistema social, cultural e com desdobramentos econômicos, como uma doença que acomete o país. Enviesamos assim o pensamento de Susan Sontag (1978) - para quem certas doenças são vistas como metáforas -, e o aplicamos ao patriarcalismo, lendo-o como se fosse uma doença, portanto, de forma metafórica.

Palavras-chave: Febre amarela - Patriarcalismo - Doença - A menina morta Cornélio Penna.

\begin{abstract}
The role of the second wave of the yellow fever epidemic in Rio de Janeiro in the novel A menina morta (1954), by Cornélio Penna (1896-1958), is unique. The episode, in addition to being sanitary, was linked to history, to social life, to politics, to economics, and to cultural and literary production. Such a transversal character contributes to transform it into a critical instrument that helps us to understand the book in question, above all, regarding patriarchalism. As the possibility of the Comendador, owner of the farm where the narrative develops, has contracted yellow fever increases, we see the system represented by him more and more weakened, undermined. From this, we think of this social, cultural and economic system as a disease that affects the country. We thus skew Susan Sontag's (1978) thought - for whom certain diseases are seen as metaphors - and apply it to patriarchy, reading it as if it was a disease, therefore, in a metaphorical way.
\end{abstract}

Keywords: Yellow fever - Patriarchalism - Disease - A menina morta - Cornélio Penna.

* Doutora em Estudos Literários pela Universidade Federal de Minas Gerais e estágio pós-doutoral pela mesma universidade. Professora Associada de Literatura Brasileira no Departamento de Letras Vernáculas e no Programa de Pós-Graduação em Letras na Universidade Federal de Sergipe. CV: http://lattes.cnpq.br/4556033791893713 


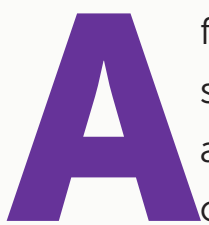

febre amarela devastou muitas vidas nos países tropicais na segunda metade do século XIX. Grande parte da devastação se deveu ao desconhecimento sobre seu agente: "A febre amarela havia sido considerada até [1901] como uma doença contagiosa clássica, propagada fosse por contato direto com um doente, fosse por contato com suas roupas, alimentos e roupa de cama, ou ainda com qualquer outro objeto contaminado" (Löwy, 2006, p. 13). Derivada desta questão, houve a divisão da classe médica, entre contagionistas e não contagionistas (Franco, 1969, p. 46). Os primeiros defendiam a quarentena e o isolamento, e os últimos afirmavam não haver qualquer prova de transmissão da febre amarela entre as pessoas.

Certamente tal disputa contribuiu para a demora em determinar como essa enfermidade ocorria e se propagava de fato. Somente no início do século $X X$, as pesquisas científicas concluíram tratar-se de "uma doença viral induzida por um vírus bem definido e transmitida ao homem pela picada de um mosquito" (Löwy, 2006, p. 22). Para termos uma melhor ideia da gravidade da situação:

Antes de 1930 [...] a identificação da febre amarela baseava-se nos sinais clínicos da doença locasionalmente enriquecidos, a partir dos anos 1920, pela observação post mortem das transformações patológicas das células do fígado de pacientes falecidos) e dos indícios epidemiológicos. (Löwy, 2006, p. 22).

Desde 1881 o médico cubano Carlos Finlay divulgava o resultado de suas pesquisas, nas quais constatou a existência de um mosquito transmissor da febre amarela. No entanto, seus estudos não alcançaram repercussão, tampouco reconhecimento, de imediato. A ignorância no meio científico nacional promovia as mais disparatadas teses a respeito das causas: indigestões, supressão da transpiração, exposição à chuva, à umidade, ao sereno e ao sol (Franco, 1969, p. 44). Portanto, na segunda metade do século XIX ainda estávamos longe de combater com eficácia a doença, porque parte da ciência se fixava nos fatores atmosféricos como agentes causadores (Franco, 1969, p. 44-45).

Enquanto a ciência se debatia em conjeturas, a febre amarela fazia mais e mais vítimas. Na primeira onda epidêmica (1849-1850), só no Rio de Janeiro, 90.658 dos 266.000 habitantes foram atingidos e 4.160 faleceram (Benchimol, 2018, p. 226).

A epidemia de febre amarela não causou apenas mortes, também produziu bens culturais. Em Lucíola (1862), de José de Alencar, a família da protagonista é acometida pela doença e vários de seus membros sucumbem. Outro exemplo é O cortiço (1890), de Aluísio de Azevedo, no qual cinco italianos padecem do mesmo mal e dois morrem. Em Memórias póstumas de Brás Cubas (1881), de Machado de Assis, a febre amarela faz mais uma vítima: Eulália perece aos 19 anos. A menina morta (1997 [1954]), ${ }^{1}$ de

1 PENNA, Cornélio. A menina morta. Rio de Janeiro: Artium, 1997. 482 p. 
Cornélio Penna (1896-1958), é outro bem cultural escrito à luz da enfermidade. Todavia, seu papel nos parece mais complexo do que nos romances anteriormente elencados, porque, além de dar novos rumos à narrativa, contribui para desvendar as engrenagens do sistema patriarcal, como se verá adiante. Para abordar A menina morta, utilizamos o método de Josefina Ludmer, aplicando-o à doença. A pesquisadora explica:

\begin{abstract}
O "delito", que é uma fronteira móvel, histórica e mutante los delitos mudam com o tempo), não só nos pode servir para diferenciar, separar e excluir, mas também para relacionar o estado, a política, a sociedade, os sujeitos, a cultura e a literatura. Como bem sabiam Marx e Freud, é um instrumento crítico ideal porque é histórico, cultural, político, econômico, jurídico, social e literário ao mesmo tempo, é uma dessas noções articuladoras que estão em ou entre todos os campos. (Ludmer, 2002, p. 11)
\end{abstract}

Impossivel não perceber esse caráter transversal e articulador da doença. Caráter reiterado por sua história, que se faz em uma verdadeira integração multidisciplinar (Teixeira; Pimenta; Hochman, 2018, p. 9). Uma enfermidade, especialmente quando toma proporções epidêmicas, marca um momento histórico, produz bens culturais, tem uma dimensão política, econômica, social, literária e, até, jurídica, pois leis são criadas e/ou alteradas para buscar controlá-la ou, ao menos, minimizá-la. Portanto, pensaremos a febre amarela em $A$ menina morta como instrumento crítico na esteira de Ludmer.

Nessa obra de ficção, escrita e publicada no século XX, mas que se situa temporalmente na segunda metade do século XIX, temos acesso à história da família Albernaz, a partir do falecimento da filha mais nova. Seus membros vivem em uma rica fazenda cafeicultora - o Grotão - às margens do rio Paraíba, na divisa entre as então províncias do Rio de Janeiro e de Minas Gerais. ${ }^{2}$ Levando-se em consideração algumas escassas informações históricas (como a Guerra do Paraguai e a própria epidemia de febre amarela), podemos situar a narrativa por volta do ano de 1870.

Cornélio Penna iniciou sua carreira artística como pintor e só depois se decidiu pela literatura. Além de A menina morta, escreveu Fronteira (1935), Dois romances de Nico Horta (1939) e Repouso (1948). Em todos esses romances há uma forte presença de personagens sofrendo de alguma doença: loucura, tuberculose, febre amarela, entre outras. O autor foi muito influenciado pelas histórias de sua família. O apreço pela manutenção dessa memória fez com que mantivesse em sua casa um quadro de um pintor desconhecido, que retratava uma tia materna morta, falecida ainda na infância (Penna, 1958, p. XXXVII). Teria sido essa parenta, que viveu em uma fazenda na mesma região do Grotão, a inspiração para a criação da menina morta - inclusive existe na narrativa a descrição de uma pintura da criança pouco antes de ser sepultada, que

2 No vale do rio Paraíba havia várias fazendas cafeicultoras que eram movidas por mão de obra escravizada. Com o crescimento da população de imigrantes europeus e a Abolição houve um deslocamento da produção para o interior de São Paulo, o que arruinou aqueles produtores. 
muito se assemelha ao quadro do pintor desconhecido. ${ }^{3} \mathrm{~A}$ primeira metade do romance é ocupada pela dor da perda da menina, perda que pode ser vista simbolicamente como o anúncio do fim do sistema patriarcal e escravocrata nos limites da fazenda. A segunda metade da narrativa trata do retorno de Carlota, a filha mais velha. A jovem, que estudava até então na Corte, deveria aplacar as dores e se casar com um rapaz escolhido por seu pai, o Comendador. Será ela a responsável por levar a cabo o fim anunciado pela morte de sua irmã.

A epidemia de febre amarela está longe de ser um acontecimento que ocupa inúmeras páginas do romance, ao contrário. A primeira menção à doença será feita na metade do livro e depois disso ressurgirá de forma eventual, quase silenciosa. Todavia, seus efeitos na economia da obra são devastadores. De fato, fala-se muito em enfermidades, mas quase nada sobre febre amarela. O silêncio - ou o silenciamento - contribui para a produção de dúvidas em torno do estado dos doentes e de que mal sofrem de fato. Nesse território de incertezas, a febre amarela ganha corpo pouco a pouco.

Em Doença como metáfora (originalmente publicado em 1978), Susan Sontag desenvolve um estudo sobre a apropriação metafórica da tuberculose e do câncer pelo senso comum e, principalmente, pela literatura. Ela afirma: "Meu tema não é a doença física em si, mas os usos da doença como figura ou metáfora" (Sontag, 2007, p. 11). Antecipa: "Minha tese é que a doença não é uma metáfora e que a maneira mais fidedigna de encarar a doença - e a maneira mais saudável de estar doente - é aquela mais expurgada do pensamento metafórico e mais resistente a ele" (Sontag, 2007, p. 11, destaque da autora). De fato, a doença não é uma metáfora para quem adoece. Todavia, costuma ser apropriada pela sociedade segundo as mais diversas formas, sobretudo pela linguagem. É o que ocorre, por exemplo, quando as pessoas utilizam uma enfermidade que lhes causa temor como metáfora para outras situações temíveis. Sontag sabe disso e seu livro, como o título indica, é um estudo sobre o movimento que metaforiza a doença, sobretudo a tuberculose e o câncer.

A observação da autora estadunidense sobre tal apropriação é bastante interessante e, portanto, pretendemos incorporá-la, ao menos em termos. O texto literário produz metáforas dos mais diversos matizes, o que nos autoriza a proceder uma aproximação entre a febre amarela e o sistema patriarcal. Naturalmente apresentaremos uma série de argumentos que justificam tal aproximação no decorrer deste artigo. Porém, adiantamos desde já uma relação inversamente proporcional em $A$ menina morta: quanto mais a febre amarela ganha corpo (e corpos), mais o patriarcalismo ${ }^{4}$ se enfraquece, debilita-se. Sendo assim, apresentaremos esse sistema como metáfora de doença nos limites do romance - que, por sua vez, pode ser lido como metáfora do

3 Este retrato hoje faz parte do acervo da Fundação Casa de Rui Barbosa.

4 Apesar de a palavra patriarcado ser mais corrente e apropriada para definir o sistema que pretendemos designar, optamos por utilizar patriarcalismo porque o seu sufixo (-ismo) é frequentemente associado a doenças. 
Brasil (Santos, 2004). ${ }^{5}$ O patriarcalismo em A menina morta guarda várias semelhanças com o apresentado por Gilberto Freyre em Casa grande \& senzala (2000 [1933]) no que se refere à sua constituição: uma família nuclear (pais e filhos legítimos) vivendo em uma grande propriedade com agregados, empregados e pessoas escravizadas, todos regidos pelo patriarca ou por algum representante seu. Segundo Costa Lima (1989), a diferença mais marcante e nada desprezível entre essas obras consiste em, por um lado, uma versão freyriana solar do patriarcalismo, na qual a violência é naturalizada, e por outro, uma versão melancólica em Cornélio Penna.

Visto que trataremos o patriarcalismo como uma doença, logo como uma metáfora, procedemos com um método de análise inverso ao proposto por Sontag. Ela partiu da doença para a metáfora, nós partimos da metáfora para a doença.

\section{Os primeiros sintomas}

Em meio aos preparativos do casamento de Carlota, a filha mais velha da família Albernaz, surge o primeiro indício de febre amarela em A menina morta. O anúncio é feito pelo Comendador:

- Creio que teremos de apressar o dia do noivado, porque devo partir para a Corte com certa urgência. Um dos meninos não está passando bem, e há verdadeira epidemia de febre amarela no Rio de Janeiro. Provavelmente teremos de receber o filho do Conde do Meal no domingo próximo, mas como o senhor ministro está preso à capital pela situação do Gabinete, diante desse impedimento a senhora virá fazer o pedido. ${ }^{6}$

Tomamos ciência, com as personagens, de que há uma epidemia assolando o Rio de Janeiro (de fato seu retorno, como veremos na próxima citação do romance). Somando os parcos indícios históricos fornecidos pela narrativa, percebe-se que estamos em 1870, ano em que a Corte foi assolada pela segunda onda epidêmica. A primeira ocorreu por volta de 1850.

À época da narrativa desenvolvida em A menina morta, a febre amarela "atingia seletivamente os imigrantes" (Löwy, 2006, p. 95), disseminando uma imagem negativa do país:

Edmond Gouy considerou o Brasil como a pátria da febre-amarela, embora reconhecendo não ser originária daqui.

Também em alguns países os nomes de "febre do Rio de Janeiro" e "mal do 'Brasil" chegaram a ser sinônimos de febre-amarela [...]. (Franco, 1969, p. 44)

Tal delimitação geográfica tornava essa doença um "grande obstáculo" para políticos

5 É o que defendemos ao longo de nossa tese de doutorado Fronteiras da nação em Cornélio Penna (2004).

6 PENNA, Cornélio. A menina morta. Rio de Janeiro: Artium, 1997, p. 297 
"adeptos das teorias raciais, de 'embranquecer' o Brasil por meio do estímulo à imigração europeia" (Löwy, 2006, p. 95), colocando-nos como país a ser evitado e reforçando "[...] uma ligação entre o imaginário da doença e o imaginário do estrangeiro. Suas raízes se encontram talvez no próprio conceito de errado, sempre identificado com o não-nós, o estranho" (Sontag, 2007, p. 115). Certamente, políticos racistas queriam fugir de tal estranhamento, pois se sentiam mais próximos dos europeus do que dos brasileiros. O desejo de embranquecimento atesta isso, pois projetaria um futuro o mais distante possível de nossas raízes indígenas e africanas.

No momento inicial de $A$ menina morta, não sabemos se a febre amarela atingiu um dos filhos do Comendador. Por mais que não se encaixe no perfil das vítimas mais frequentes da enfermidade - os estrangeiros -, é evidente que há uma ameaça pairando sobre o menino. Além disso, há uma interferência direta no noivado de Carlota com João Batista, pois o Senhor precisará viajar ao encontro do filho doente. Apesar da ausência dos dois patriarcas, o noivado não deve ser adiado. Diante de outras informações veiculadas no romance, somos levados a considerar que a interferência causada pela doença pode, até certo ponto, ser bem-vinda, já que o Comendador deseja que o enlace se dê o mais breve possível, para aplacar uma suposta vergonha. Esse sentimento estaria ligado à Dona Mariana, ao que tudo indica banida da fazenda por suas atitudes contrárias às do marido. O comportamento gerador do exílio da Senhora seria seu pedido da encomenda da alma de um dos escravizados ao padre da região. Na versão oficial, o rapaz teria se suicidado na mata, após ter atentado contra a vida do Comendador. Nas demais versões ele teria sido assassinado pelos feitores e outros escravizados, a mando do proprietário.

Sendo assim, os arranjos para o noivado e para o casamento de Carlota são assumidos pela Condessa, mãe do noivo, e por Dona Virgínia, prima do Comendador - ambas alinhadas e aliadas aos princípios do patriarcalismo.

Ainda no mesmo episódio da citação anterior do romance, uma das parentas pergunta:

- Qual dos dois meninos, primo Comendador? Espero que não seja nada de grave...

- É o mais moço - respondeu secamente o Senhor - e o médico do colégio ao me escrever não diz de que mal se trata, mas pede a minha presença. Penso, depois de ter refletido bem sobre isso, mandá-los para a Europa onde estudarão melhor, talvez na Suiça, no Grand-Lancy.

- Meu Deus - murmurou baixinho Sinhá Rola - então não veremos mais nenhum deles, e o caçula ainda é tão criança...

[...] Toda essa pantomima [de D. Inacinha para Sinhá Rola não ser ouvida pelo Senhor] foi inútil, porque o Comendador já se erguera e fora até a porta onde estavam os homens, para contar-lhes todas as notícias recebidas sobre o Gabinete ameaçado de interpelação que prometia ser ruidosa, sobre a volta da febre amarela. ${ }^{7}$

Aqui tomamos conhecimento de que é o filho mais novo quem está doente e, também, sobre o tipo de solução que as famílias abastadas davam para os problemas epidemiológicos

7 Idem, p. 298. 
(ainda quando não havia certezas): o afastamento de seus membros dos centros irradiadores e a fuga para a Europa. Outro ponto importante é a economia nas informações que o Comendador concede às mulheres da casa. Para elas, apenas o comunicado e a resposta seca. Para os demais - homens na maioria das vezes, apenas de passagem -, a conversa camarada e "todas as notícias recebidas". Se, por um lado, o Senhor é econômico nas palavras dirigidas às mulheres, por outro, percebemos que elas não ousam ou não devem ousar, como fez Sinhá Rola, dirigir-lhe questões ou opiniões, porque, se o fizerem, receberão respostas secas ou não serão propositalmente ouvidas. O patriarca pouco fala com as senhoras e com todos aqueles que the servem, para não precisar ouvi-los, uma estratégia para neutralizar possíveis adversários. Esse procedimento é recorrente ao longo do romance e muito contribuirá para o clima de mistério e ignorância constantes que envolvem as mulheres, sobretudo aquelas que não estão devidamente alinhadas ao patriarcalismo ou que não gozam da confiança do Senhor.

Quando mencionamos o clima de mistério, aproximamos a obra de Cornélio Penna de um universo específico e produtivo na literatura, pelo menos desde o advento da narrativa gótica. Porém, se utilizamos a palavra ignorância, avizinhamos seu texto da não ciência dos fatos. A menina morta trabalha com certa dualidade, entre o sobrenatural de um lado, e o natural do outro. Se, por determinado prisma, a febre amarela aproxima o romance de uma prosa mais realista, pois é compatível com a epidemia que assolou o Rio de Janeiro no século XIX, por outro, sua imprecisão (o menino está ou não com a doença, por exemplo) reitera seu aspecto misterioso. Tal imprecisão é reforçada pela dificuldade de a ciência daquele momento histórico diagnosticar uma doença, muitas vezes confundida com outras "febres" (Löwy, 2006, p. 25), e das quais não se conseguia distinguir o agenciamento. Para efeito deste estudo, interessa-nos trabalhar as questões relativas à ciência e à não ciência dos fatos, pois é à febre amarela e suas consequências no romance, que direcionamos nosso olhar.

Assim, observamos que o estado de ignorância se reapresentará em diferentes situações ao longo da narrativa, sempre acometendo as mulheres e, sobretudo, Carlota. Mesmo sendo a futura proprietária da fazenda, a jovem é mantida propositadamente afastada dos acontecimentos que envolvem a vida de todos à sua volta. Quando ela recebe um bilhete da futura sogra, temos uma evidência dessa condição:

Ao dobrar o papel lançou as vistas sobre a missiva da fazendeira vizinha e leu: "seu estimado Pai ainda se demora na Corte, preso por doença..." e sentiu suas mãos se tornarem geladas a ponto de ter de largar depressa o papel e escondê-las no regaço. Aquela pessoa estranha, talvez inimiga, estava informada de seu pai estar enfermo, sabia de suas resoluções de seus projetos, e ela, a filha, tudo ignorava. ${ }^{8}$

Apesar de não dizer qual doença tomou o Comendador e de não entrar em pormenores, a Condessa conhece seu estado, enquanto Carlota só sabia até então da enfermidade do irmão. Em uma conversa com Celestina, única parenta com quem tem alguma afinidade,

8 Idem, p. 334. 
a jovem reafirma tudo ignorar: "eu não sei se meu pai está doente! não sei por que ele foi embora, não sei quando voltará!". ${ }^{9}$ Em meio à ignorância em que é mantida, Carlota passa a desconfiar também das parcas informações que obtém, como as do bilhete da Condessa "talvez inimiga". A ignorância assume um caráter de espalhamento similar ao de uma doença epidêmica. Ambas atingem sistematicamente novas vítimas.

Todavia, para esclarecer melhor a dinâmica do romance, é preciso retomar a ideia de que o Comendador apenas comunica às mulheres da fazenda sobre a doença do filho mais novo, e que tal comunicação se dá de forma lacônica. Em outras palavras, é o proprietário da fazenda e aquilo que ele representa, o patriarcalismo, que administram o silêncio, a interdição e a ignorância ali reinantes. Portanto, a ignorância é mais um sintoma do que uma doença, a doença seria o patriarcalismo.

A Condessa tem conhecimento da doença do Comendador porque ele escolhe informá-la, porque ambos estão do mesmo lado. Não à toa ela utiliza maiúscula quando o menciona: Pai. Tal uso reafirma o lugar de poder do patriarca. Carlota não sabe de sua doença porque ele escolhe não a informar, porque ambos estão em lados opostos - o que ficará cada vez mais nítido com o avançar da narrativa. Logo, se a Condessa "talvez fosse inimiga" de Carlota, seu próprio pai também o era, pois o patriarcalismo é inimigo do feminino por princípio. Isso não significa dizer que não tenha a seu serviço mulheres. A complexidade do sistema não permitiria jamais limitá-lo apenas a homens, é preciso que mulheres estejam em suas fileiras para aumentar o raio de atuação e transmitir seus princípios, visto serem nesse contexto as responsáveis pela educação das crianças e coadjuvantes na repressão a outras mulheres.

Gerir o tráfego de informações é uma, entre outras, forma de controle sobre as mulheres do Grotão e, principalmente, sobre Carlota. Mantida à parte dos acontecimentos, a jovem fica sob o domínio do Comendador - e afastada do domínio de Dona Mariana e da resistência que ela representa. Não à toa, enquanto o Senhor está associado ao mistério (à escuridão), ao interdito e ao silenciamento, a Senhora estará associada à tentativa de se comunicar, de denunciar e à clareira (à iluminação), seu local preferido para passeios. Nesse sentido, a febre amarela enfeixa uma série de fatos que se mantêm mais ou menos distanciados do conhecimento de Carlota, sempre conformes aos desejos do Senhor. Tal associação é pertinente, pois a ciência, como mencionado, demorou algumas décadas para desvendar a forma como a febre amarela era transmitida, o que contribuiu para que as mais diversas conjecturas fossem produzidas entre a população e para aumentar o clima de verdadeiro pânico que a doença instaurou no país.

Adiante, Carlota parece incorporar o estado de ignorância no qual o patriarcalismo e seus agentes (homens ou mulheres) tentam mantê-la, pois ao receber cartas não as abre de imediato, possivelmente porque sabia que não seria por elas esclarecida de nada. A senhora Luísa, governante da casa, indaga a jovem:

\section{- Não nos vai dar novas do senhor Comendador? Ouvi contar, quando}

9 Idem, p. 363 
a senhora Condessa esteve aqui, que ele e o menino estavam muito doentes... Será a horrível febre amarela? Tenho estado todo o tempo a pensar nisso, mas não consigo nunca estar a par de nada...

Carlota corou intensamente e baixou os olhos para o regaço, apesar de ter o folheto entre os dedos aberto na página de modas e ficou calada, sem encontrar qualquer resposta, pois sentia sobre si a atenção observadora e perspicaz das companheiras.

- Mas nós também recebemos cartas do primo Comendador - observou singelamente Sinhá Rola - e posso informar-lhe, senhora Luísa, que tudo está bem, e ele breve virá para o Grotão.

Dona Inacinha encolheu os ombros desanimada, porque não quisera explicar à irmã serem apenas frases convencionais as por elas recebidas e nada queriam dizer, pois eram apenas manifestações da maneira sempre correta e afável do parente ao tratá-las. ${ }^{10}$

Carlota se envergonha de sua ignorância equiparada à da governante, também ela "não conseguia nunca estar a par de nada". Ela, futura proprietária do Grotão, sabe tanto quanto a empregada ou até menos, pois seus passos são vigiados por Dona Virgínia. Notamos mais uma vez que essa ignorância se estende a todas as mulheres que não são da confiança do Comendador, pois Sinhá Rola e Dona Inacinha igualmente são alijadas do real estado de saúde dele, recebendo "apenas frases convencionais". No entanto, as duas irmãs têm outras fontes, pois gozam de um pouco mais de liberdade do que Carlota. Haja vista que: "As notícias que haviam chegado sobre a sua doença [do Comendador] as deixara apreensivas e amarguradas, pois se o Grotão mudasse de senhor, quem seria o novo?". ${ }^{11}$ Portanto, percebendo a ameaça que a doença e o futuro proprietário (provavelmente o marido de Carlota) implicavam, ambas as irmãs passam a planejar estratégias de saída da fazenda.

\section{A confirmação em doses homeopáticas}

As cogitações em torno da febre amarela parecem cessar quando Dona Virgínia, a prima mais próxima do Comendador, demonstra confiar plenamente em sua recuperação:

- O nosso sangue é muito forte, todo ele de povoadores e de homens fundadores de cidades e de fazendas onde os indios flechavam os negros, e não será a febre amarela que o vença...

Carlota não pôde esconder o choque recebido [...].12

Esse trecho do romance contém aspectos interessantes. Notamos que são atribuídas força e resistência à febre amarela, baseadas no sangue, portanto, qualidades advindas de ancestrais do Comendador. Uma ancestralidade feita "de povoadores e de homens

10 Idem, p. 370-371.

11 Idem, p. 371.

12 Idem, p. 372. 
fundadores". Assim, ele faz parte de uma linhagem de exploradores bandeirantes, pessoas que, como sabemos, escravizavam, matavam e violentavam todos os que se interpunham no caminho. Evidentemente essa não é a ótica de Dona Virgínia, pois ela tem muito orgulho de pertencer a tal linhagem. Diferentemente de seus antepassados, o Senhor não necessita iniciar povoações, pois alguém já fez isso por ele. Sua posição é de desfrute das conquistas obtidas por aqueles que o precederam. O romance nos informa que o Grotão é parte da herança que os pais legaram, assim como a Boa Vista, a fazenda vizinha, e tudo que ambas contêm: casagrande, senzala, enfermaria, sala de castigo, escravizados e mulheres. O Comendador é o pater familias, porque este é o seu legado e ele não está disposto a perdê-lo. No que depender de Dona Virgínia, sempre fiel, ele não perderá.

A doença e a fraqueza seriam para aqueles que não se encaixam dentro da estrutura patriarcal ou para as mulheres. Essas mencionam o temor às enfermidades diversas vezes. Celestina chega a ser tomada pela tuberculose. Todavia, na visão de Dona Virgínia, o Comendador estaria acima de qualquer problema de saúde. Ele tudo pode, inclusive contra a doença e, portanto, contra a morte. Em termos ela está certa porque a ordem patriarcal que representa mantém-se ou pode ser mantida, mesmo após seu falecimento. Nega-se a morte de um sujeito de poder porque o estado das coisas do qual ele é parte integrante está garantido. Vislumbra-se, assim, uma espécie de eternidade da exploração de muitos, pelas mãos de uns poucos. A família Albernaz estaria acima de tudo, inclusive das enfermidades, pois o patriarcalismo seguiria firme e robusto, como se fosse intocável e incontestável.

Retomando a citação acima, estamos diante do primeiro momento no qual se fala de forma direta sobre o fato de o Comendador ter sido acometido pela temida febre amarela. Negando que ele sucumbirá à doença, Dona Virgínia termina por publicá-la, o que deixa Carlota em choque. Fica evidente que ela obtém a informação de segunda mão, a mão de Dona Virgínia, portanto alguém que se configura como sua inimiga. Seu pai não lhe dá acesso de moto próprio aos acontecimentos que lhe dizem respeito. Quando a jovem tem alguma notícia vinda dele é porque todos os demais já estão cientes. Se não todos os demais, ao menos Dona Virgínia, como fica evidente nesta próxima passagem, na qual responde a uma indagação dessa senhora: "- Como já sabe, [a carta] é de meu pai e ele me diz que está doente, e por esse motivo adiou a sua volta ao Grotão, mas breve nos avisará do dia de sua chegada". ${ }^{13}$ As informações contidas na carta do Comendador à sua filha a equiparam à Sinhá Rola e Dona Inacinha, pois aparentemente Carlota recebera "apenas frases convencionais". Sim, ela toma conhecimento de que o pai está doente, mas, ao afirmar que em breve avisará sua chegada, dá a entender tratar-se de uma enfermidade leve e passageira, portanto distante da funesta febre amarela, comentada por Dona Virgínia no momento anterior. Assim, a jovem prossegue detida por um círculo de ignorância, que a impede de entender o que, de fato, se passa à sua volta e quais os rumos a tomar referentes à sua vida - rumos sempre controlados pelo Comendador, mesmo quando distante e doente.

Páginas adiante, Bruno, o escravizado que acompanhara o Comendador à Corte, retorna

13 Idem, p. 376, destaque nosso. 
ao Grotão para pegar mais dinheiro, a mando do proprietário. Em um primeiro momento ele tem contato apenas com Manuel Procópio, único parente homem a viver na fazenda. Diante da curiosidade natural de Carlota sobre o estado do pai, o familiar diz apenas: "Parece-me não estar bem, e nada escreveu, apenas o documento para eu entregar o dinheiro ao portador" ${ }^{14} \mathrm{~A}$ jovem se mantém - ou é mantida - mais uma vez no território das incertezas. Porém, o fato de o Senhor precisar enviar um escravizado para pegar mais dinheiro denota que algo não corre de acordo com as expectativas, e talvez esteja mesmo fora de controle. Carlota então desiste do parente e indaga diretamente Bruno:

- [...] Nós éramos para voltar da Corte agora, mas se não fosse a febre do Sinhozinho, que está na casa do senhor comissário junto com meu amo, já estaríamos todos aqui.

- Diga-me o que sabe sobre meu pai - tornou a murmurar Carlota [...].

- O senhor Comendador também está doente - murmurou depois de abaixar a cabeça o pajem - mas mandou dizer que não é nada... ${ }^{15}$

Por meio do escravizado, Carlota toma ciência, mais uma vez, que o Senhor não lhe diz o que de fato ocorre. Ele omite e mente para melhor controlá-la e para que ela concretize o casamento arranjado. A jovem entende que terá melhores informações pelos escravizados e libertos do que pelos membros da sua família, pois estes não sabem de nada ou sabem tão pouco quanto ela, ou não contam o que sabem. Para isso, Carlota precisará superar as duras palavras do pai, que desprezava quem dava ouvidos aos "mexericos de negras"16 e, por extensão, de negros. Administrar o trabalho dos cativos no eito e na casa-grande era uma coisa, mas administrar o que falavam era bem mais complexo. Por isso, o Senhor desautorizava tudo o que diziam, colocando-os como meros intrigantes, e desautorizava aqueles e, sobretudo, aquelas que lhes dessem qualquer atenção. A cada dia mais ciente desse movimento, a jovem contraria o pai e passa a ouvir e indagar os que a servem. Libânia, sua mucama, revela um pouco mais:

- O Sinhozinho está com febre amarela! Sinhazinha, Deus nos valha! Que irá acontecer?

- Foi o Bruno que lhe contou?

- Antes de vir dormir eu fiquei esquentando fogo na cozinha por causa da umidade, e ele estava lá também... e nos disse ter o menino sido tirado do colégio e levado para a casa do senhor Comissário Socorro, seu parente, porque não queriam que ele fosse para o lugar chamado lazareto, e estavam todos lá muito aflitos, até o meu Senhor que parecia estar doente também e não saía do quarto. ${ }^{17}$

Assim, Carlota obtém a confirmação de que o irmão mais novo fora acometido pela febre amarela e se encontra em estado grave. Tal passagem, como a anterior, mostra que os

14 Idem, p. 392.

15 Idem, p. 393.

16 Idem, p. 383.

17 Idem, p. 394. 
negros e as negras da fazenda estão melhor informados do que acontece na distante cidade do Rio de Janeiro, do que sua proprietária. Na verdade, a jovem é proprietária, mas não senhora. Ela fora dotada com o Grotão para tornar o casamento mais atraente à família de João Batista, mas o comando de tudo e de todos continua nas mãos do seu pai ou de seus representantes - e Carlota sem dúvida não é um deles.

Destacamos, ainda, na citação anterior, que fora cogitado transferir o menino doente, do colégio para um lazareto. Ora, como vimos no início deste trabalho, segundo Franco (1969, p. 46), os lazaretos eram locais de tratamento e isolamento defendidos por médicos que acreditavam que a febre amarela era contagiosa. Apesar de ricos e poderosos, os Albernaz estavam sujeitos à mesma sorte de indefinições científicas que quaisquer outras pessoas. Constatamos, portanto, que, em certo sentido, Carlota espelha tais indefinições e dúvidas. Vejamos para isso a passagem a seguir, quando João Batista, recém retornado do Rio de Janeiro, lhe faz uma visita. Ela pergunta:

- Viu meu pai na Corte?

- Vi, sim - respondeu ele, e pareceu a Carlota que tivera uma quase imperceptivel hesitação, e seus olhos se tinham perturbado - está de cama conforme já sabe, mas tem continuado a tratar de seus negócios, e recebe muita gente, e se entretém em longas conferências. [...]

- E meus irmãos? [...]

- Ah, seus irmãos... o mais velho não me foi possível ver, mas o caçula está também enfermo, e não sei se já sabe, os médicos desconfiam ser febre amarela o seu mal...18

Logo, para o noivo: o Comendador estaria doente, mas não mal, pois prossegue tratando de negócios e recebe pessoas com as quais conversa por muito tempo. Todavia, não escapa a Carlota a "quase imperceptível hesitação", colocando o relato sob suspeita. Essa suspeita só aumenta quando João Batista fala do irmão mais novo. Ao contrário de Libânia, que havia tido contato com Bruno, que por sua vez estivera no Rio de Janeiro, acompanhando o Senhor, o noivo afirma que os médicos apenas "desconfiam ser febre amarela o seu mal...". Logo, ele dá uma versão mais palatável do estado de saúde de seu pai e de seu irmão, do que fizera o rapaz escravizado. João Batista lhe dá a versão, digamos, oficial daquilo que o Comendador desejava que ela soubesse. Nessa versão, o domínio do Grotão e da vida dos seus moradores prossegue nas mãos de seu pai, pois ele estaria suficientemente saudável para se manter em atividade. Portanto, Carlota continuaria subjugada. Não se trata de mantê-la na total ignorância, o que seria praticamente impossível, mas conforme temos insistido, de controlar seu acesso com essa terapêutica, na qual se inocula o problema - de que o Comendador está com febre amarela - em doses homeopáticas, ou seja, pequenas. O resultado mais evidente de tal terapia é deixar a jovem sem ação, sem poder de oposição ou revolta diante do destino que lhe é imposto: casar-se com alguém que se alinha às prerrogativas de seu pai, ao patriarcalismo e aos seus mecanismos de controle e poder. Ao lado de João Batista, Carlota está acompanhada

18 Idem, p. 420. 
de mais um inimigo, de mais uma pessoa que furta a verdade e que a manterá subjugada.

As palavras do noivo reiteram as de D. Virgínia, já mencionadas: "O nosso sangue é muito forte, todo ele de povoadores e de homens fundadores de cidades e de fazendas onde os índios flechavam os negros, e não será a febre amarela que o vença...". ${ }^{19}$ A mesma força que teria permitido aos ancestrais do Comendador fundarem cidades e fazendas, não permitiria que ele fosse vencido pela doença. Indiretamente os indígenas, que ameaçavam tal força, são comparados à febre amarela. Os povos originários combatiam o patriarcalismo escravocrata. Mas, se os antepassados venceram aquela "doença" - ainda que por meio da força dos negros que escravizavam - o Comendador, como em uma guerra, vencerá a febre amarela e tudo poderá permanecer "como sempre foi".

Todavia, o inimigo a ser atacado não se parece com uma doença, ele é uma doença. Enquanto o patriarcalismo segue aparentando robustez e saúde, a ciência ainda é pouco eficaz no combate à febre amarela.

\section{O diagnóstico irrefutável}

A prova final de quem mentia e de quem revelava o que realmente acontecia surge, quando a jovem recebe uma carta da Corte:

Carlota manteve sobre si muito tempo a missiva a ela entregue, coberta de obreias pretas, presas entre os dedos. Não podia reunir as ideias, e sua cabeça parecia oca, ressoante como a ampla gruta onde se precipitasse a corrente rápida de algum rio, e qualquer movimento por ela feito provocava dores agudas em sua nuca. Notara surpresa estar o papel debruado de preto, e bem sabia ser seu significado a morte de alguém, mas estava agora certa dessa perda nada significar em sua vida [...].

Foi, pois, devagar, timidamente, que rasgou o papel e leu a notícia da morte do Comendador, cujas forças não tinham resistido à febre amarela, e falecera horas depois de seu filho mais moço, vitimado pela mesma doença. O parente, em cuja casa estivera doente o Senhor, em frases curtas dizia ter prevenido, pelo correio elétrico, da gravidade do estado de ambos. ${ }^{20}$

É assim que Carlota toma plena ciência, não apenas da intensidade da doença que levara seu pai e seu irmão, mas de que se tratava realmente da terrível febre amarela, tantas vezes referida e agora, enfim, ratificada. Ela confirma de forma definitiva como as notícias lhe eram furtadas, pois jamais recebera o correio elétrico mencionado pelo parente que acusava quão crítico era o estado do Comendador. Não à toa, a jovem "estava agora certa dessa perda nada significar em sua vida". Afinal, não havia recebido qualquer sinal de atenção ou afeto advindo do pai. Ele não a poupara dos acontecimentos dolorosos, ele a interditara de conhecêlos.

Somente a morte do Comendador possibilita que Carlota saiba. Não que ela não

19 Idem, p. 372.

20 Idem, p. 443. 
soubesse de nada antes. Todavia, a ciência do que ocorria na fazenda e com os seus the era encoberta por uma série de mistérios, que nada mais eram do que desinformações, mentiras ou apagamentos. Portanto ela precisou romper com barreiras, para conhecer o que de fato acontecia à sua volta, especialmente no que dizia respeito à vida dos escravizados e à sua mãe. É a viagem de seu pai à Corte em um primeiro momento, e sua morte em outro, que possibilitarão a Carlota saber e ação. Ainda que sob forte vigia, na ausência do Senhor, ela consegue adentrar mais nos eventos da fazenda. A união do que vê, do que ouve e do que lembra de seus tempos de criança a ajudarão a entender o que significa o sistema de exploração que a todos controla, inclusive a ela própria.

\section{As sequelas}

Antes da morte do Comendador e após passar a dar mais atenção aos relatos dos negros e, especialmente, das negras, Carlota desobedece as regras às quais era submetida e perambula só à noite pelas dependências externas à casa. Nessa caminhada ouve um gemido e se aproxima de uma das construções onde:

[...] percebeu alguns móveis estranhos com pontas que furavam o ar de forma esquisita, e logo compreendeu mais do que viu ter sido uma árvore inteira deitada junto da parede do fundo. O ronco ritmado e muito regular [do gemido que ouvira antes] partia dali, mas às vezes destacava-se dele o lamento profundo e sombrio por ela já escutado e agora ouvido distintamente. Procurou a porta, e ao achá-la deu volta à taramela simples que a prendia, e entrou na quadra atijolada e foi até a parede fronteira. Realizou então serem escravos no tronco, e lembrou-se a sorrir das histórias contadas de que a menina morta ia "pedir negro"... Mas, o sorriso gelou-se em seus lábios, porque agora via o que realmente se passava, quais as consequências das ordens dadas por seu pai e como aqueles homens velhos, os feitores de longas barbas e de modos paternais, que a tratavam com enternecido carinho, cumpriam e ultrapassavam as penas a serem aplicadas. Sabia agora o que representava o preço dos pedidos da menina morta, que a ela custavam apenas algumas palavras ditas com meiguice. E teve ódio da criança ligeira de andar dançante, a brincar de intervir, vez por outra, em favor daqueles corpos que via agora contorcidos pela posição de seus braços e pernas, presos no tronco, e cujo odor de feras enjauladas Ihe subia estonteante às narinas. Parecia-lhe monstruosa a cena, no entretanto muitas vezes vívida em sua memória, e tantas outras contadas pelas mulheres e irmãs daqueles agora diante dela, sem sequer a olharem se estavam mesmo acordados, na certeza de ser ela alguma aparição infernal, talvez alguém mandado para averiguar se sofriam tanto quanto fora determinado... ${ }^{21}$

Essa citação é fundamental para compreendermos não apenas a dimensão do choque de Carlota diante da violência próxima a ela, como a violência em si. Todavia, em primeiro

21 Idem, p. 413. 
lugar, o ódio direcionado à irmã morta merece uma explicação. Quando viva, como o excerto deixa claro, a menina costumava pedir que os escravizados não fossem castigados. Os feitores atendiam tais pedidos, ou melhor, adiavam as torturas para outro momento e para longe de seus olhos inocentes. Na verdade, não só a criança era poupada do espetáculo sórdido, mas todos aqueles que permaneciam ou deveriam permanecer na casa-grande, ou seja, as senhoras. A princípio, Carlota só vê os castigos sendo aplicados porque rompe com o círculo que a protegia e a controlava, impedindo-a de sair de casa desacompanhada, por exemplo. $O$ ódio que sente da irmã, no fundo, é direcionado a si própria, pois, quando criança, costumava roubar chapinhas ${ }^{22}$ dos feitores para dá-las aos cativos, também prática comum da menina morta. Ora, não é difícil intuir que aqueles homens de "longas barbas e de modos paternais" apenas interpretavam o papel de logrados para ambas, pois, eram as filhas do fazendeiro.

A crueldade com a qual eram tratados os escravizados da fazenda quando não cumpriam as exigências do Comendador se apresenta aqui sem meios tons. Nada poderia contrariar seus desejos: fossem sexuais, fossem de tortura, fossem de morte. Logo às primeiras páginas do romance sabemos de suas visitas noturnas à senzala feminina. As torturas e a possível morte estão expostas na citação acima, além do assassinato de Florêncio, já comentado. Assim, tomamos conhecimento do que aquele senhor rico e refinado, que estudou na França e vestia os melhores trajes, era capaz, quando suas vontades não eram realizadas ou eram contrariadas por qualquer motivo. Todavia, como a citação explicita, não há exatamente novidade na cena cruel para Carlota, porque estava "vívida em sua memória" e situações similares lhe foram "contadas pelas mulheres e irmãs daqueles agora diante dela". Portanto, até então, a violência era naturalizada, inclusive por ela. O que ocorre neste momento é uma conscientização.

Apesar de ciente da violência reinante no Grotão, Carlota segue de mãos atadas. Ela fora dotada pelo pai, mas isso não acarreta que se torne a administradora de seus bens. A iminência do casamento com João Batista, sendo quem ele é, e do lado que está, só reforça a continuidade do patriarcalismo. Ao contrário do Comendador, que retirava da vista das senhoras a violência, o noivo não se constrange com cenas públicas. Em uma das visitas do rapaz, um trintanário que o acompanhava tenta tirar pesada carga da vitória. Neste instante Carlota:

[...] viu o escravo receber em cheio o caixote sobre um dos pés, pois não o conseguira reter na sua queda brusca, ao se romperem as correias que o prendiam às grades do assento. Mais rápido ainda, o moço [João Batista] agarrou o preto pelo peito da japona por ele vestida e fustigou-o às cegas em furiosos golpes com o chicote que trazia na mão direita. O trintanário recebeu as chicotadas que deviam marcar profundamente a sua carne, mal protegida pela pobre libré por ele envergada, sem qualquer gesto de defesa, sem experimentar fugir ou se proteger, nem mesmo tirar o pé debaixo do engradado, a esmagá-lo. Mantinha os olhos muito abertos sem expressão, e era semelhante ao animal resignado à dor por ele sabida inevitável, e entregava-se à vontade do dono sem restrições, esquecido até dos primeiros instintos das criaturas. 
Carlota teve vontade de correr, de gritar, de rasgar o seu vestido, mas apenas pôde manter-se imóvel agarrada ao balaústre do alpendre e tinha certeza de que se dele desprendesse os dedos cairia no chão sem amparo. Nunca pôde saber quanto tempo ali estivera, nem de que maneira conseguira manter-se, mas viu João Batista, o noivo, enxugar o rosto coberto de suor pela violência de seus movimentos, reajustar a gravata, cujas dobras se tinham desfeito, alisar a calça e fazer correr as mãos pelas pernas e só então deu pela sua presença e veio ao seu encontro iluminado pela alegria e com a naturalidade dos noivos.

Carlota continuara sem vê-lo, os olhos fixos no escravo, que ao ver afastar-se o seu amo, passara com presteza a manga da véstia no rosto, e também se arrumara todo, para depois pôr o caixote nos ombros a fim de trazê-lo para o alpendre onde ao chegar saudou jovialmente, como se nada se tivesse passado com ele:

- Sua bênção, Nhanhã!

E após colocar a carga no chão, ficou à espera do moço cumprimentar a jovem e depois lhe dar novas ordens. Carlota custou a arrancar os olhos daquele rosto sorridente, para atender ao visitante curvado diante dela, em risonha galantaria. Mas não pôde estender-lhe a mão que lhe pesava caída sobre o vestido e parecia morta. ${ }^{23}$

Essa cena aviltante demonstra que a crueldade patriarcal não era de forma alguma circunscrita ao Comendador. João Batista participa dela ativamente, não se importando em dissimular nada. Tampouco delega a terceiros a violência, aplica-a ele próprio, diante de todos. O noivo banaliza e naturaliza mais a crueldade, quando se dirige com alegria a Carlota. 0 casamento de ambos fatalmente daria continuidade ao sistema explorador, aprisionador e violento. Como agente ou como vítima, de alguma maneira, todos estavam contaminados pelo patriarcalismo.

É assim que a morte do Comendador configura uma oportunidade única de rompimento deste ciclo. Após alguns obstáculos causados pela Condessa, Carlota consegue alforriar todos os escravizados. Esvaziada a fazenda de sua mão de obra, também estará esvaziada de um importante atrativo para a realização do casamento. Casamento nunca desejado pela jovem e reduzido a interesses morais pelo seu pai, e econômicos para a família de João Batista, um mero negócio. Portanto, com um único gesto, a filha do Comendador liberta os escravizados e se liberta de imposições sociais e familiares.

No entanto, tal atitude, além de ter consequências funestas para o Grotão, não é bem vista pelos agora ex-cativos, o que Carlota não considera, pois:

[...] de nada queria saber, e mergulhava com alívio na solidão e no silêncio feitos em torno dela, pois só via sombras que se esgueiravam à sua aproximação, como se tivesse sido lançado sobre a fazenda terrivel malefício. Nenhum dos negros viera agradecer-lhe a liberdade, e as mucamas a espreitavam aterrorizadas, na mesma atitude de seus antepassados das florestas africanas diante da divindade malfazeja e incompreensivel, vinda misteriosamente para tomar o lugar da

23 Idem, p. 367-368. 
Sinhazinha-nova, da menina morta, adorada por elas todas [...]. ${ }^{24}$

O terror dos ex-escravizados é compreensível, afinal, não foram libertados, foram abandonados. Passado o choque inicial:

[...] pouco a pouco, ora um negro sozinho, ora algum feitor seguido por pequeno número de homens sob suas ordens, enfim mulheres, os filhos presos às ancas possantes, vieram até o seu reduto [de Manuel Procópio], para com ele falarem e, sem plano definido, sem ordem, sem compreender bem qual seria o resultado de tudo aquilo, tendo em mãos apenas criaturas apavoradas diante da queda súbita de suas algemas, e que se sentiam mutiladas de forma irreparável, ele foi reconstituindo a máquina feita em pedaços. Lentamente, tal o organismo ferido de morte que reage e se põe a reviver vida vegetativa, até poder sustentar-se em agonia lenta de muitos anos, a vida da enorme propriedade agrícola se refez, dentro de outro ritmo, sem a antiga pujança, desaparecida para sempre. ${ }^{25}$

Apesar de as expressões "ferido de morte" e "vida vegetativa" se referirem ao Grotão, vemos aqui a sustentação mais evidente para a relação estabelecida desde o início deste artigo: o patriarcalismo como doença. Afinal, é na fazenda que esse sistema se desenvolve. Morto seu principal representante, o patriarcalismo, como a propriedade, entra "em agonia lenta de muitos anos", como em uma longa enfermidade sem cura. Ora, um organismo em tal estado não pode dominar, não pode controlar, tampouco subjugar.

\section{Considerações finais}

O patriarcalismo, como uma doença, é aniquilador. Ele corroeu todas as relações, inclusive as familiares. O Comendador se mantinha no controle da "enfermidade" porque se beneficiava dela e não se importava com aqueles que dela padeciam. Todavia, a febre amarela encerrou seu domínio. Aquele ser altivo, refinado e autoritário tomba diante de uma doença tropical e epidêmica, portanto, de caráter coletivo. Ironicamente, ele se torna vítima das más condições sanitárias que seu meio social ajudou a criar. Apesar de não fazer parte do principal grupo de risco da febre amarela, os estrangeiros, ao avaliar que os filhos estavam sob perigo, o Comendador cogita enviá-los à Europa, revelando o olhar das classes mais abastadas sobre elas mesmas. Os ricos e poderosos se comportavam no século XIX como se fossem colonizadores europeus, pouco ou nada identificados com a recém-nascida nação - a não ser naquilo que significasse a manutenção de privilégios -, sempre agindo como estrangeiros, prontos a partir ao primeiro sinal de ameaça.

Portanto, o Brasil nasceu doente de patriarcalismo. A Abolição e a industrialização funcionaram como medicamentos, mas ainda hoje restam vestígios da enfermidade, percep-

24 Idem, p. 459.

25 Idem, p. 458. 
tíveis na disparidade de salários entre homens e mulheres, na violência doméstica contra estas e na manutenção dos homens em lugar central na maioria das famílias contemporâneas, nas quais muitas vezes prosseguem sendo servidos e nutridos por mães, esposas, companheiras, filhas, empregadas domésticas.

O fato é que a febre amarela que acometeu o Comendador possibilitou à sua filha consciente e afetada em algum grau pela violência reinante -, a libertação dos escravizados e sua própria, das amarras que a ligariam a João Batista, um homem tão ou mais nocivo que seu pai. Contudo, tal gesto, como o da Abolição no Brasil, não veio acompanhado de amparo. Mal realizada, a libertação configurou-se na dimensão do abandono, do "salve-se quem puder". A condição jurídica da pessoa ex-escravizada foi alterada, mas não a social e tampouco a econômica - ao menos não na mesma direção de emancipação. É por isso que o longo período de escravidão continua a causar transtornos. Segundo Wander Melo Miranda, o autor de A menina morta se ocupou com:

[...] o resgate da herança do passado, onde se localizaria o processo de formação da nossa nacionalidade, que o período escravocrata traduz sob a forma de um violento dissenso. Ao colocá-lo em cena como nenhum outro romancista entre nós, Cornélio Penna não só estaria problematizando a pretensa unidade que nos constituiria enquanto nação, mas assinalando a permanência de um conflito não sanado na origem e que, sob a forma de um fantasma desagregador, continua a nos assombrar e a nos manter exilados no passado, como num pesadelo que parece não ter fim. (Miranda, 1997, p. 482)

O pesquisador menciona literalmente a escravidão, mas o patriarcalismo está subentendido, pois foi esse sistema que administrou a exploração contra os indígenas inicialmente e depois contra os negros. Pacientes adoecidos de um passado violento, só nos resta expiar nossos fantasmas. Para Derrida, o intelectual

[...] deveria aprender a viver aprendendo não a conversar com o fantasma, mas a ocupar-se dele, dela, a deixar-lhe ou restituir-lhe a fala, seja em si, no outro, no outro em si: eles estão sempre aí, os espectros, mesmo se eles não existem, mesmo se eles não são mais, mesmo se eles não são ainda. (Derrida, 1994, p. 234, destaque do autor)

Paremos então de falar e entreguemo-nos a ouvir.

\section{Referências Bibliográficas}

BENCHIMOL, Jaime Larry. Revolução pasteuriana na saúde pública e na pesquisa biomédica brasileiras (1880 a 1920). In: TEIXEIRA, Luiz Antônio; PIMENTA, Tânia Salgado; HOCHMAN, Gilberto (org.). História da saúde no Brasil. São Paulo: Hucitec, 2018. p. 225-283. 
COSTA LIMA, Luiz. A aguarrás do tempo: Estudos sobre a narrativa. Rio de Janeiro: Rocco, 1989. $363 \mathrm{p}$.

DERRIDA, Jacques. Espectros de Marx: O Estado da dívida, o trabalho do luto e a nova Internacional. Tradução de Anamaria Skinner. Rio de Janeiro: Relume-Dumará, 1994. $234 \mathrm{p}$.

FRANCO, Odair. História da febre amarela no Brasil. Rio de Janeiro: Ministério da Saúde, 1969. 209 p.

FREYRE, Gilberto. Casa grande \& senzala: Formação da família brasileira sob o regime da economia patriarcal. 41. ed. Rio de Janeiro: Record, 2000. 668 p.

LÖWY, Ilana. Vírus, mosquitos e modernidade: A febre amarela no Brasil entre ciência e política. Tradução de Irene Ernest Dias. Rio de Janeiro: Editora Fiocruz, 2006. 427 p.

LUDMER, Josefina. Introdução. In: LUDMER, Josefina. O corpo do delito: Um manual. Tradução de Maria Antonieta Pereira. Belo Horizonte: Ed. UFMG, 2002. p. 7-18.

MIRANDA, Wander Melo. Posfácio. In: PENNA, Cornélio. A menina morta. Rio de Janeiro: Artium, 1997. p. 472-482.

PENNA, Cornélio. Romances completos. Rio de Janeiro: José Aguilar, 1958. 1462 p.

SANTOS, Josalba Fabiana dos. Fronteiras da nação em Cornélio Penna. 2004. Tese (Doutorado em Estudos Literários) - Programa de Pós-Graduação em Estudos Literários, Universidade Federal de Minas Gerais, Belo Horizonte, 2004. 262 p.

SONTAG, Susan. Doença como metáfora: Aids e suas metáforas. Tradução de Rubens Figueiredo e Paulo Henriques Britto. São Paulo: Companhia das Letras, 2007. 163 p.

TEIXEIRA, Luiz Antônio. PIMENTA, Tânia Salgado. HOCHMAN, Gilberto. História da saúde no Brasil: uma breve história. In: TEIXEIRA, Luiz Antônio; PIMENTA, Tânia Salgado; HOCHMAN, Gilberto (org.). História da saúde no Brasil. São Paulo: Hucitec, 2018. p. $9-26$.

Recebido em: 30 de setembro de 2020

Aprovado em: 15 de janeiro de 2021 